\title{
Editorial \\ Special Issue on the Histopathology of Aquatic Animals
}

\author{
Božidar Rašković ${ }^{1,2, *(\mathbb{D}) \text { and Panagiotis Berillis }}{ }^{3}$ (D) \\ 1 Institute of Animal Science, Faculty of Agriculture, University of Belgrade, 11080 Belgrade, Serbia \\ 2 Department of Microscopy, Institute of Biomedical Sciences Abel Salazar (ICBAS), University of Porto, \\ 4050-313 Porto, Portugal \\ 3 Department of Ichthyology and Aquatic Environment, School of Agricultural Sciences, University of Thessaly, \\ 38446 Volos, Greece; pveril@uth.gr \\ * Correspondence: raskovic@agrif.bg.ac.rs; Tel.: +381-11-441-32-89
}

check for

updates

Citation: Rašković, B.; Berillis, P. Special Issue on the Histopathology of Aquatic Animals. Appl. Sci. 2022, 12, 971. https://doi.org/10.3390/ app12030971

Received: 11 January 2022

Accepted: 13 January 2022

Published: 18 January 2022

Publisher's Note: MDPI stays neutral with regard to jurisdictional claims in published maps and institutional affiliations.

Copyright: (c) 2022 by the authors. Licensee MDPI, Basel, Switzerland. This article is an open access article distributed under the terms and conditions of the Creative Commons Attribution (CC BY) license (https:// creativecommons.org/licenses/by/ $4.0 /)$.

\section{Introduction}

Histopathology is the study of changes in any tissue associated with a disease or disorder. The word came from ancient Greek words: $\iota \sigma \tau o ́ \varsigma($ histos) $=$ tissue, $\pi \dot{\alpha} \theta$ o $\zeta$ (pathos) = disease, and $\lambda$ oyi $\alpha$ (logia) $=$ word. It involves the examination of tissues and cells under a microscope in order to identify the alterations to the normal structure of tissues (and perhaps their etiology). Information obtained from the study of histopathological/histomorphological lesions in aquatic animals can be a useful addition when determining the general state of health of aquatic animals, especially if chronic stressors and/or pathogens are present. Compared to mammals, postmortem autolysis progresses very rapidly in most aquatic organisms. This fact makes histopathological examinations quite complex and demanding, not only in a histotechnical sense. A prerequisite for a successful study is the baseline knowledge of physiological processes and histological architecture of the studied species.

The aim of this Special Issue was to contribute to the current state of knowledge on the histopathology of aquatic animals and to provide a collection of novel articles for biologists/veterinarians/animal scientists/other experts. The topic is extremely broad, and therefore, the published manuscripts are also diverse in terms of research areas, employed methodology and investigated species. Eight original studies and two review articles are part of this Special Issue and their short overview by two Guest Editors is given below.

\section{Fish Nutrition}

In fish nutrition trials, histopathology is frequently used to describe subtle alterations in tissues and cells of the digestive system upon the addition of novel ingredients or the replacement of fish meal in fish feed [1,2]. If the growth parameters of fish are not satisfactory or are lagging compared to the control group of fish or available literature data, the histological approach could provide researchers with possible answers for this phenomenon. Often, new ingredients in fish feeds will not cause significant histopathological alterations but will have an effect on the appearance of cells involved in the absorption or transformation of molecules that originate from the feed, such as enterocytes in the intestine or hepatocytes in the liver, respectively [3]. Their surface area or volume can be determined using various histological techniques, and a decreased size of cells (or their nuclei) is a marker for metabolic and physiological differences of organs in fish that are fed alternative feeds [4]. However, some antinutritional factors in plant-based fish feed have inflammatory effects on the distal intestine of fish, causing enteritis. This happens in both carnivorous and omnivorous fish [5,6], although the intensity and extent of enteritis is more pronounced in carnivorous fish species.

Rombenso et al. [7] studied the origin of enteritis in Atlantic salmon (Salmo salar) fed soybean meal derived from specific soybean genotypes, which had reduced content of lipoxygenases and oligosaccharides, as well as an altered glycinin profile. They concluded that neither of these substances is a driver of distal intestine inflammation, as they did not 
influence the extent of enteritis in Atlantic salmon. Psofakis et al. [8] conducted a feeding study of gilthead seabream (Sparus aurata) for 56 days with feeds in which fishmeal was replaced by poultry by-product meal and hydrolyzed feather meal in various concentrations. The nutritional trial showed that higher levels $(>50 \%)$ of replacement caused severe liver pathologies, such as cirrhosis and necrosis of pancreatic acini. On the other hand, there was no intestine inflammation, but the histological structure of the intestine remained without pathological features, which is a nice demonstration of why two (or possibly more) organs should be included in histological studies. Both studies published in this Special Issue used a semi-quantitative scoring system as a means to evaluate histopathological changes in the intestines and livers of experimental fish.

\section{Exposure Studies}

Histopathology is one method of choice in exposure assays, as it could give mechanistic insight into toxicological pathology [9]. Several guidance documents are published by the Organisation for Economic Co-operation and Development (OECD) and the US Environmental Protection Agency (EPA) for conducting standardized exposure assays on aquatic animals. The guidelines cover a number of experimental species, different life stages and exposure scenarios, thus giving the possibility of inter-laboratory comparison. Depending on the choice of stressor in exposure assays, researchers will target different organs and assess the change of its micro-architecture.

One group of authors published two manuscripts in this Special Issue from a single experiment in which an amphibian, Xenopus laevis, was exposed to atrazine, a frequently used herbicide (at least in the United States, since the European Union banned it) in a dose-dependent approach. The effects of exposure are evaluated on the histology of the heart and cerebellum [10] and liver and kidney [11]. Immunohistochemical markers were used on the same types of tissue, and the authors opted for caspase- 3 in the liver and kidney and Inositol 1,4,5-trisphosphate in the heart and cerebellum. Both studies showed significant adverse effects of the herbicide on the tissues, with a range of different histopathological alterations most frequently observed in the liver and kidney of this frog. Histomorphometrical methods were further employed in order to show changes on a range of different cells and structures in the mentioned tissues. Gómez de Anda et al. [12] exposed rainbow trout (Oncorhynchus mykiss) fingerlings to a bath containing several species of Aeromonas spp. They found several histopathological alterations of nervous tissues (nasal epithelium, telencephalon, and oblongata medulla), which were distinct to the fish infected with $A$. lusitana and $A$. salmonicida and with the higher severity grades. Fish infected with other bacterial species had middle-to-less severity and distribution of histopathological alterations.

\section{Environmental Studies}

The state of freshwater or marine ecosystems worldwide is frequently monitored in order to assess the general health of the aquatic animals inhabiting it. Usually, a battery of biomarkers is employed during monitoring, with histopathology being one of them, in order to obtain as much information as possible from the sampled fish [13]. A similar approach is used for studies published in this Special Issue. Three published manuscripts used histopathological methodology to investigate tissues of interest on various cyprinid fish from ecosystems of the Balkan Peninsula. The case study of lipoma found in the liver of the black barbel (Barbus balcanicus) in the Bregalnica River (North Macedonia) was described by Rebok et al. [14]. This agglomerate of adipocytes was assessed microscopically after being serially sectioned, while the authors also reconstructed a 3D image after applying software. Tsakoumis et al. [15] studied the histopathology of gills in the endemic fish species Alburnus vistonicus over one year in Vistonis Lake (Greece). The ecosystem of this lake is, according to the authors, "peculiar", in the sense that it is a mixture of freshwater (originated from three rivers) and seawater (from the Aegean Sea). Therefore, salinity levels fluctuate due to the seasonal activity of rivers, and the authors monitored the mentioned 
fish species using a battery of biomarkers, including histopathology, in order to establish a correlation between salinity and alterations of fish gills. A similar use of histopathology as a biomarker in the study of fish in a natural ecosystem is conducted in the Tamiš river (Serbia) [16]. This river is burdened with the presence of metals that originate from anthropogenic activity. The authors used a semi-quantitative scoring system to assess the gills of the common bream (Abramis brama) in order to study the effects of water quality during two seasons (autumn and spring aspect).

\section{Review Manuscripts}

The review papers are focused on two hot topics in environmental pollution: pesticides and micro/nanoplastics. In both articles, histopathology is used as a marker of effects, and it is one of the several biomarkers that were reviewed. Tresnakova et al. [17] presented an overview of the effects of glyphosate and its major metabolite AMPA in different formulations to various species of fish, amphibians and aquatic invertebrates. Endpoints included: hematological parameters, blood biochemistry, gene expression, oxidative stress biomarkers and antioxidant enzymes. Glyphosate is the most frequently used herbicide worldwide, but recently, it sparked controversy in the EU [18]. Guerrera et al. [19] wrote a comprehensive and detailed review paper of the effects of micro- and nanoplastics on aquatic organisms, accounting for ten chapters in total. Special focus is given to the bloodbrain barrier in fish, neurotoxicity, adverse effects in fish gills, intestine, liver and gills, while one chapter is dedicated to toxicity of micro- and nanoplastics to zebrafish (Danio rerio).

\section{Conclusions}

Histopathological techniques can provide a more analytical view of disease and its effect on tissues and cells. Histopathology helps ichthyopathologists to reach a diagnosis by examining a small piece of tissue from various organs. This Special Issue confirms statements that the histopathological method does not have limitations in terms of laboratory setup, choice of ecosystem, climate or aquatic species investigated. This method is employed on very different species in terms of phylogeny, age, sex and physiology, with a range of different tissues investigated and various research scopes, in both laboratories and the field. The different evaluation techniques of sections were chosen depending on the goals of the particular study. We hope that this collection of manuscripts will be useful to readers and scientists working in the area of histology/histopathology of aquatic organisms and that it will further increase interest in this scientific area.

Author Contributions: Conceptualization, B.R. and P.B.; methodology, B.R. and P.B.; investigation, B.R.; writing —original draft preparation, B.R.; writing-review and editing, P.B. All authors have read and agreed to the published version of the manuscript.

Funding: This research received no external funding.

Institutional Review Board Statement: Not applicable.

Conflicts of Interest: The authors declare no conflict of interest.

\section{References}

1. Rašković, B.; Stanković, M.; Marković, Z.; Poleksić, V. Histological methods in the assessment of different feed effects on liver and intestine of fish. J. Agric. Sci. 2011, 56, 87-100.

2. Randazzo, B.; Zarantoniello, M.; Gioacchini, G.; Cardinaletti, G.; Belloni, A.; Giorgini, E.; Faccenda, F.; Cerri, R.; Tibaldi, E.; Olivotto, I. Physiological response of rainbow trout (Oncorhynchus mykiss) to graded levels of Hermetia illucens or poultry by-product meals as single or combined substitute ingredients to dietary plant proteins. Aquaculture 2021, 538, 736550. [CrossRef]

3. Ostaszewska, T.; Dabrowski, K.; Palacios, M.E.; Olejniczak, M.; Wieczorek, M. Growth and morphological changes in the digestive tract of rainbow trout (Oncorhynchus mykiss) and pacu (Piaractus mesopotamicus) due to casein replacement with soybean proteins. Aquaculture 2005, 245, 273-286. [CrossRef]

4. Rašković, B.; Cruzeiro, C.; Poleksić, V.; Rocha, E. Estimating volumes from common carp hepatocytes using design-based stereology and examining correlations with profile areas: Revisiting a nutritional assay and unveiling guidelines to microscopists. Microsc. Res. Tech. 2019, 82, 861-871. [CrossRef] [PubMed] 
5. Baeverfjord, G.; Krogdahl, Å. Development and regression of soybean meal induced enteritis in Atlantic salmon, Salmo salar L., distal intestine: A comparison with the intestines of fasted fish. J. Fish Dis. 1996, 19, 375-387. [CrossRef]

6. Urán, P.A.; Gonçalves, A.A.; Taverne-Thiele, J.J.; Schrama, J.W.; Verreth, J.A.J.; Rombout, J.H.W.M. Soybean meal induces intestinal inflammation in common carp (Cyprinus carpio L.). Fish Shellfish Immunol. 2008, 25, 751-760. [CrossRef] [PubMed]

7. Rombenso, A.N.; Blyth, D.; James, A.T.; Nikolaou, T.; Simon, C.J. Lipoxygenase Enzymes, Oligosaccharides (Raffinose and Stachyose) and 11sA4 and A5 Globulins of Glycinin Present in Soybean Meal Are Not Drivers of Enteritis in Juvenile Atlantic Salmon (Salmo salar). Appl. Sci. 2021, 11, 9327. [CrossRef]

8. Psofakis, P.; Meziti, A.; Berillis, P.; Mente, E.; Kormas, K.A.; Karapanagiotidis, I.T. Effects of Dietary Fishmeal Replacement by Poultry By-Product Meal and Hydrolyzed Feather Meal on Liver and Intestinal Histomorphology and on Intestinal Microbiota of Gilthead Seabream (Sparus aurata). Appl. Sci. 2021, 11, 8806. [CrossRef]

9. Wester, P.W.; Van der Ven, L.T.M.; Vethaak, A.D.; Grinwis, G.C.M.; Vos, J.G. Aquatic toxicology: Opportunities for enhancement through histopathology. Environ. Toxicol. Pharmacol. 2002, 11, 289-295. [CrossRef]

10. Asouzu Johnson, J.; Nkomozepi, P.; Opute, P.; Mbajiorgu, E.F. Cardiac and Cerebellar Histomorphology and Inositol 1,4,5Trisphosphate (IP3R) Perturbations in Adult Xenopus laevis Following Atrazine Exposure. Appl. Sci. 2021, 11, 10006. [CrossRef]

11. Sena, L.; Asouzu Johnson, J.; Nkomozepi, P.; Mbajiorgu, E.F. Atrazine-Induced Hepato-Renal Toxicity in Adult Male Xenopus laevis Frogs. Appl. Sci. 2021, 11, 11776. [CrossRef]

12. Gómez de Anda, F.R.; Vega-Sánchez, V.; Reyes-Rodríguez, N.E.; Martínez-Juárez, V.M.; Ángeles-Hernández, J.C.; AcostaRodríguez, I.; Campos-Montiel, R.G.; Zepeda-Velázquez, A.P. The Nasal Epithelium as a Route of Infection and Clinical Signs Changes, in Rainbow Trout (Oncorhynchus mykiss) Fingerlings Infected with Aeromonas spp. Appl. Sci. 2021, 11, 9159. [CrossRef]

13. Van der Oost, R.; Beyer, J.; Vermeulen, N.P. Fish bioaccumulation and biomarkers in environmental risk assessment: A review. Environ. Toxicol. Pharmacol. 2003, 13, 57-149. [CrossRef]

14. Rebok, K.; Jordanova, M.; Azevedo, J.; Rocha, E. First Report and 3D Reconstruction of a Presumptive Microscopic Liver Lipoma in a Black Barbel (Barbus balcanicus) from the River Bregalnica in the Republic of North Macedonia. Appl. Sci. 2021, 11, 8392. [CrossRef]

15. Tsakoumis, E.; Tsoulia, T.; Feidantsis, K.; Mouchlianitis, F.A.; Berillis, P.; Bobori, D.; Antonopoulou, E. Cellular Stress Responses of the Endemic Freshwater Fish Species Alburnus vistonicus Freyhof \& Kottelat, 2007 in a Constantly Changing Environment. Appl. Sci. 2021, 11, 11021.

16. Marinović, Z.; Miljanović, B.; Urbányi, B.; Lujić, J. Gill Histopathology as a Biomarker for Discriminating Seasonal Variations in Water Quality. Appl. Sci. 2021, 11, 9504. [CrossRef]

17. Tresnakova, N.; Stara, A.; Velisek, J. Effects of Glyphosate and Its Metabolite AMPA on Aquatic Organisms. Appl. Sci. 2021, 11, 9004. [CrossRef]

18. Kudsk, P.; Mathiassen, S. Pesticide regulation in the European Union and the glyphosate controversy. Weed Sci. 2020, 68, 214-222. [CrossRef]

19. Guerrera, M.C.; Aragona, M.; Porcino, C.; Fazio, F.; Laurà, R.; Levanti, M.; Montalbano, G.; Germanà, G.; Abbate, F.; Germanà, A. Micro and Nano Plastics Distribution in Fish as Model Organisms: Histopathology, Blood Response and Bioaccumulation in Different Organs. Appl. Sci. 2021, 11, 5768. [CrossRef] 